\title{
Analysis of Relationship between Land Surface Temperature and Land Use in Colombo Municipal Area in Sri Lanka, Using Geographical Information System and Remote Sensing
}

\author{
M.A.D. Samanmali ${ }^{*}$, S.P.M. Siriwardane ${ }^{2}$ \\ ${ }^{l}$ Department of Geography, University of Colombo, Sri Lanka \\ ${ }^{2}$ GIS Solutions (Pvt.) Ltd, Sri Lanka \\ *mataraarachchids@gmail.com
}

\begin{abstract}
The recent climatological studies try to find out the relationship between land surface temperature and land use type. Specially urban and industrial area was selected for that study, as well as this study was done in Colombo Municipal Council (CMC). The CMC area was central industrial and economical area in Sri Lanka. The majority of people travel to the Colombo Metropolitan area daily for their needs. In the present, both developed and developing countries face to global warming. As the developing country in Sri Lanka, industrial and vehicle usage was very high in the city center in Colombo. In that case land surface temperature (LST) increased day by day.

The main objective of this study to analyse the LST using Landsat TM, $\mathrm{ETM}^{+}$and Landsat 8 images. In addition find out the relationship between LST and land use in CMC area. Arc GIS 10.1 and ERDAS 2014 software were used for this study. It was found out the LST range from $22^{\circ} \mathrm{C}$ to $33^{\circ} \mathrm{C}$. Some of the high temperature zones are shown in Fort and Maradana. Generally there was a high building density (commercial and industrial) and traffic density in while the day. In 1987 high temperature was also recorded close to the Fort and Maradana. However, it has gradually increased to the other areas. It was seen that the impact of that LST distributes to the southern part of the CMC. In addition, all the LST of all areas of $\mathrm{CMC}$ passed minimum $30^{\circ} \mathrm{C}$ during the day time.
\end{abstract}

Keywords: Land surface temperature, Remote sensing, Land use, Colombo 